DOI: $10.14720 /$ aas.2016.107.1.21

Agrovoc descriptors: climatic factors; meteorological factors; less favoured areas; agricultural products; water balance; air temperatures

Agris category code: $\mathrm{P} 40, \mathrm{f} 01$

\title{
Priprava klimatskih podlag kot dodatnega kriterija za določanje območij z omejenimi možnostmi za kmetijsko dejavnost
}

\author{
Tjaša POGAČAR ${ }^{1}$, Ajda VALHER $^{2}$, Mateja ZALAR ${ }^{3}$, Zalika ČREPINŠEK ${ }^{4}$, Lučka KAJFEŽ-BOGATAJ ${ }^{5}$
}

Received Janury 26, accepted March 07, 2016.

Delo je prispelo 26. januarja 2016, sprejeto 07. marca 2016.

\section{IZVLEČEK}

Analizirali smo klimatske značilnosti Slovenije v obdobju 1981-2010, ki so predlagane za določitev območij z omejenimi možnostmi za kmetijsko dejavnost (OMD). Po navodilih Evropske komisije, ki jih je pripravil Joint Research Centre (JRC), je potrebno izračunati 30-letna povprečja za kriterij nizkih teperatur zraka (dolžina rastne dobe in vsote efektivnih temperatur zraka) in kriterij aridnega podnebja (indeks sušnosti $A I$ ). Dodatno smo izračune opravili tudi po metodi Agencije RS za okolje (ARSO), ki se pri določanju temperaturnih pragov nekoliko razlikuje od metode JRC. Po kriteriju nizkih temperatur zraka so pod pragom za OMD le hribovitejši predeli, najnižja uvrščena meteorološka postaja je v Ratečah. Glede na kriterij aridnega podnebja se nobeno območje v Sloveniji ne uvrsti med OMD, zato smo dodatno analizirali meteorološko vodno bilanco. $\mathrm{V}$ povprečju se je $\mathrm{v}$ obdobju 1981-2010 glede na obdobje 1971-2000 na večini lokacij zmanjšala. Vplivi podnebnih sprememb se kažejo v prisotnih trendih pri obravnavanih spremenljivkah, zato pri določanju OMD priporočamo izračune in upoštevanje trendov oziroma redne ponovitve analiz.

Ključne besede: območja $\mathrm{z}$ omejenimi možnostmi $\mathrm{za}$ kmetijsko dejavnost (OMD), rastna doba, vsota efektivnih temperatur zraka, kazalec sušnosti AI, meteorološka vodna bilanca

\section{ABSTRACT \\ CALCULATION OF CLIMATE FACTORS AS AN ADDITIONAL CRITERIA TO DETERMINE AGRICULTURALLY LESS FAVOURED AREAS}

Climate factors that are proposed to determine agriculturally less favoured areas (LFA) in Slovenia were analyzed for the period 1981-2010. Following the instructions of European Commission prepared by Joint Research Centre (JRC) 30years averages of low air temperatures criteria (the vegetation period duration and sums of effective air temperatures) and aridity criteria (aridity index $A I$ ) have to be calculated. Calculations were additionally done using Slovenian Environment Agency (ARSO) method, which is slightly different when determining temperature thresholds. Only hilly areas are below the LFA low air temperatures threshold with the lowest located meteorological station in Rateče. According to aridity criteria no area in Slovenia is below the threshold, so meteorological water balance was also examined. Average water balance in the period 1981-2010 was in most of locations lower than in the period 1971-2000. Climate change impacts are already expressed as trend presence in time series of studied variables, so it is recommended to calculate trends and take them into account or to perform regular iterations of calculations.

Key words: agriculturally less favoured areas (LFA), vegetation period, sum of effective air temperatures, aridity index AI, meteorological water balance

\footnotetext{
dr., Univerza v Ljubljani, Biotehniška fakulteta, Jamnikarjeva 101, SI-1000 Ljubljana, tjasa.pogacar@bf.uni-lj.si

2 AJDA, Ajda Valher s.p., Gorenjskega odreda 8, SI-4000 Kranj, ajda.valher@gmail.com

3 Univerza v Ljubljani, Biotehniška fakulteta, Jamnikarjeva 101, SI-1000 Ljubljana, mateja. zalar@bf.uni-lj.si

4 doc. dr., Univerza v Ljubljani, Biotehniška fakulteta, Jamnikarjeva 101, SI-1000 Ljubljana, zalika.crepinsek@bf.uni-lj.si

prof. dr., Univerza v Ljubljani, Biotehniška fakulteta, Jamnikarjeva 101, SI-1000 Ljubljana, lucka.kajfez.bogataj@bf.uni-lj.si
} 


\section{UVOD}

Skupna kmetijska politika si z uvajanjem različnih ukrepov za različne vloge kmetijstva (npr. gospodarsko, prostorsko, ekološko, socialno) glede na Program razvoja podeželja RS za obdobje 2007-2013 (Program..., 2009) prizadeva za trajnostni razvoj kmetijstva. Del tega so tudi plačila za območja $\mathrm{z}$ omejenimi možnostmi za kmetijsko dejavnost (OMD), ki so namenjena ohranjanju proizvodnje in kulturne krajine na teh območjih in jih je v Sloveniji trenutno 86,3\% celotne površine. Slovenija je v obdobju 20072013 izvajala izravnalna plačila za OMD po treh skupinah kriterijev: za hribovsko gorska območja, območja $\mathrm{s}$ posebnimi omejitvami in druga območja. Do sedaj so bili upoštevani standardni omejitveni dejavniki in z njimi povezani kriteriji (nagib kmetijskih zemljišč, zemljiška in parcelna razdrobljenost, talne razmere, nadmorska višina) in regionalno specifični omejitveni dejavniki ter $\mathrm{z}$ njimi povezani kriteriji (kraško površje, poplave, močni vetrovi, erozija) (Program..., 2009).

V okviru Ciljnega raziskovalnega programa »Zagotovimo.si hrano za jutri« smo v projektu $\gg$ Klimatske podlage kot dodatni kriterij za območja z omejenimi možnostmi za kmetijsko dejavnost (OMD)« analizirali spremenljivke, ki so predlagane za določitev tretje skupine, to je drugih območij z naravnimi omejitvami, in se navezujejo na njihove klimatske značilnosti. Pri tem smo sledili reformi drugih območij z OMD, ki poteka na ravni Evropske unije (EU) (Uredba EU, št. 1305/2013, člen 32). Metodologijo za določanje območij z OMD glede na biofizikalne kriterije so za Evropsko komisijo pripravili na Joint Research Centre (JRC) (Updated..., 2012). Naša analiza je zajemala dolžino rastne dobe, vsote efektivnih temperatur zraka za rastno dobo in sušni stres rastlin, pri čemer smo obvezani slediti metodam dela po JRC. Ker se v Sloveniji v splošni praksi na Agenciji RS za okolje (ARSO) uporabljajo nekoliko drugačne metode dela, smo izračune pripravili tudi po teh, kar Ministrstvu za kmetijstvo, gozdarstvo in prehrano nudi dodatno informacijo o obravnavanih spremenljivkah.

Klimatski kriteriji so določeni tako, da upoštevajo potrebno toploto za razvoj poljščin in da določijo morebitne sušne razmere. Kriterij nizkih temperatur zraka je določen na podlagi dolžine rastne dobe in vsote efektivnih temperatur zraka $\mathrm{v}$ rastni dobi. Pomemben je s kmetijskega vidika, saj nizke temperature zraka omejujejo rast in razvoj rastlin preko vpliva na njihovo zgradbo, razmnoževanje in pomembne fiziološke procese, kot sta na primer fotosinteza in olistanje. Nizke temperature zraka so definirane kot dejavnik, pri katerem je preživetje rastlin ali njihova produktivnost omejena, torej temperaturne razmere niso zadostne za njihov obstoj, optimalno rast in razvoj (Updated ..., 2012). Kriterij aridnega podnebja pa je ob daljših obdobjih brez dežja še pomembnejši omejitveni dejavnik za rast in razvoj kmetijskih kultur.

Sušnik in Žust (2008) sta za potrebe vmesne diskusije na Evropskem svetu po naročilu tedanjega Ministrstva za kmetijstvo, gozdarstvo in prehrano leta 2007 pripravili izračune dolžine rastne dobe in vsote efektivnih temperatur zraka za rastno dobo za Slovenijo za določen nabor glavnih meteoroloških postaj za obdobje 1961-2007. Izkazalo se je, da dolžina rastne dobe v Sloveniji za večino nižinskih kmetijskih pridelovalnih območij ni omejevalni dejavnik glede na mejne vrednosti. Pri analizi vsot efektivnih temperatur zraka sta ugotovili, da so tudi območja $\mathrm{v}$ hribovitih predelih (med 600 in $1000 \mathrm{~m}$ nadmorske višine) nad mejnimi vrednostmi. Kot zaključek sta navedli, da so za naše razmere meje temperaturnih kriterijev preostre in zato neustrezne za slovenske razmere.

Kot glavni omejitveni dejavnik se v Sloveniji vedno pogosteje omenja sušnost (Sušnik, 2014). $\mathrm{Na}$ sušnejših območjih je kmetijstvo precej omejeno z možnostmi glede izbora poljščin in $\mathrm{z}$ manjšim pridelkom. Obstaja sicer veliko različnih kazalcev suše, vsak s svojimi prednostmi in omejitvami (Sušnik, 2014). Večinoma so zasnovani na osnovnih meteoroloških spremenljivkah: temperatura zraka, padavine in potencialna evapotranspiracija. Za izračun OMD mora biti kazalec suše preprost za izračunavanje, temeljiti pa mora na osnovnih meteoroloških meritvah. Pri suši v kmetijstvu so izrednega pomena tudi tla, ta pa so že ločeno vključena $\mathrm{v}$ obravnavo OMD, čeprav bi morali upoštevati interakcijo $\mathrm{z}$ meteorološkimi spremenljivkami. Kljub temu, da je Slovenija bogata z vodnimi viri, 
vsi podatki kažejo, da zaradi pomanjkanja padavin ali njihove neugodne časovne razporeditve, suša predstavlja tveganje tudi pri nas. Slovenija porabi za odpravo posledic suše $\mathrm{v}$ kmetijstvu veliko sredstev in žal deluje na področju suš nekonsistentno in brez dobro definiranih kompetenc (Pogačar in sod., 2014).

\section{METODE IN MATERIAL}

\subsection{Dolžina rastne dobe in vsote efektivnih temperatur zraka}

Dolžina rastne dobe je po JRC (Updated..., 2012) določena kot število dni med (vključenim) spomladanskim in (izključenim) jesenskim pragom. Spomladanski prag oziroma začetek rastne dobe je določen $\mathrm{s}$ petim dnem, ko je $\mathrm{v}$ petih zaporednih dneh povprečna dnevna temperatura zraka nad $5{ }^{\circ} \mathrm{C}$. Podobno je jesenski prag oziroma konec določen kot peti dan, ko je vsaj pet zaporednih dni povprečna dnevna temperatura zraka pod $5{ }^{\circ} \mathrm{C}$. Vsote efektivnih temperatur zraka določimo tako, da $\mathrm{v}$ rastni dobi na podlagi dnevnih povprečnih temperatur zraka seštejemo presežke povprečne dnevne temperature zraka nad temperaturo praga $5{ }^{\circ} \mathrm{C}$.

Predvsem zaradi zimskih otoplitev v jugozahodni Sloveniji ter zgodnje spomladanskih otoplitev drugod po nižinski Sloveniji, ki trajajo več kot pet dni, pa ARSO uporablja drugačno definicijo za doseganje temperaturnega praga. Spomladanski prag nastopi prvi dan vsaj 6 dni dolgega intervala s povprečno temperaturo zraka, večjo od temperature praga po koncu zadnjega vsaj 6 dni dolgega intervala $s$ povprečno temperaturo zraka manjšo od temperature praga. Jesenski prag nastopi prvi dan prvega 6-dnevnega intervala $\mathrm{s}$ povprečno temperaturo zraka, manjšo od temperature praga (ARSO, 2014). Definiciji JRC in ARSO se torej razlikujeta za en dan v dolžini zahtevanega intervala in $\mathrm{v}$ dnevu, na katerega nastopi temperaturni prag (pri JRC je to zadnji dan intervala, pri ARSO pa prvi dan).

Izračune smo po obeh metodah izvedli za sedem meteoroloških postaj, ki so si različne po nadmorski višini ter zastopajo različne regije Slovenije (označene na sliki 1). Izračunane vrednosti smo primerjali z mejnimi vrednostmi za OMD po JRC (Updated..., 2012): vsota efektivnih temperatur zraka mora biti manjša od $1500{ }^{\circ} \mathrm{C}$ ali pa dolžina rastne dobe krajša od 180 dni. Pri kriterijih za OMD se dodatno upošteva medletno variabilnost meteoroloških razmer, zato je po navodilih JRC priporočeno uporabiti pristop $80 \% / 20 \%$. Ta predvideva, da se območje uvrsti med območja omejena $\mathrm{z}$ nizkimi temperaturami zraka, če so vsaj v $20 \%$ let oziroma sedmih letih od obravnavanih 30 dolžine rastnih dob ali vsote efektivnih temperatur zraka pod določenim pragom.

\subsection{Sušnost}

V okviru evropske kmetijske politike in OMD je primanjkljaj vode $\mathrm{v}$ tleh definiran $\mathrm{z}$ letnim številom dni s primanjkljajem vode. Primankljaj vode $\mathrm{v}$ tleh pomeni, da količina padavin in razpoložljive vode $\mathrm{v}$ tleh $\mathrm{v}$ primerjavi $\mathrm{s}$ potencialno evapotranspiracijo ni zadostna, da bi rastline lahko napredovale s produkcijskim ciklom (Updated..., 2012). Za določitev OMD po JRC je izbran kazalec indeks sušnosti $A I$ (Aridity Index), ki je določen kot razmerje med letno količino padavin $(R R)$ in letno potencialno evapotranspiracijo $\left(E T_{p}\right): \quad A I=R R / E T_{p}$ (Updated..., 2012). Za območja z OMD veljajo tista, pri katerih so vrednosti $A I$ pod 0,5. Za primer smo izbrali dve glavni meteorološki postaji v Sloveniji, ki imata glede na padavinsko karto korigiranih padavin za dolgoletno obdobje 19712000 (Povprečna..., 2014) najmanj (Murska Sobota - Rakičan) in največ (Rateče) padavin. Za obe smo za obdobje 1981-2010 na letni ravni in ravni vegetacijskega obdobja (od začetka aprila do konca septembra) izračunali $A I$. Žal sistematičnih meritev potencialne evapotranspiracije $\mathrm{v}$ Sloveniji ni. Izjema so lizimetri, ki pa niso del merilne mreže ARSO (Zupanc in sod., 2012). Zato ima izbira dobre računske metode za oceno evapotranspiracije še poseben pomen. Priporočena je uporaba Penman-Monteithove metode (Allen in sod., 1998), ki je tudi za Slovenijo že večkrat preizkušena in je v stalni uporabi na ARSO.

Že pred začetkom projekta smo predvidevali, da za Slovenijo kazalec $A I$ zelo verjetno ne bo pokazal sušnosti in se zato odločili za dodatno analizo 
meteorološke vodne bilance. Ta se izračuna kot razlika med količino padavin in potencialno evapotranspiracijo na dnevni skali, obravnavali pa smo vsote meteorološke vodne bilance $\mathrm{v}$ vegetacijskem obdobju.

\subsection{Statistična analiza}

Osnovna statistična analiza je bila predpisana $\mathrm{s}$ strani JRC. Izračunali smo povprečne vrednosti obravnavanih spremenljivk v 30-letnem obdobju in medletno variabilnost, izraženo $\mathrm{v}$ številu let, ko je vrednost spremenljivke pod določenim pragom. Dodatno smo za izbranih sedem postaj pogledali časovne vrste spremenljivk, da bi dobili vpogled, ali obstaja trend ali jih lahko obravnavamo kot stacionarne. Izračunali in prikazali smo drseče sredine reda 10, s katerimi smo želeli preveriti, ali se $\mathrm{v}$ časovni vrsti kaže prisotnost trenda. $\mathrm{V}$ tem primeru se moramo namreč zavedati, da se povprečje v obravnavanem obdobju spreminja, kar pomeni, da so rezultati metod, ki temeljijo samo na povprečju, pristranski.

\subsection{Podatki}

Za izračun dolžine rastne dobe in vsote efektivnih temperatur zraka smo potrebovali povprečne dnevne temperature zraka, za izračune kazalca sušnosti in meteorološke vodne bilance pa dnevne izmerjene količine padavin in izračunane vrednosti dnevne potencialne evapotranspiracije. $\mathrm{Za}$ vse izračune in analize smo uporabljali podatke meteoroloških meritev ARSO (ARSO, 2014) za obdobje 1981-2010, za meteorološko vodno bilanco pa dodatno podatke o padavinah in potencialni evapotranspiraciji $\mathrm{v}$ obdobju 19712000 (z izjemo postaj Krvavec, Sevno, Maribor letališče, Lesce, Metlika in Portorož, ki v tem obdobju nimajo dovolj dolgega niza podatkov).

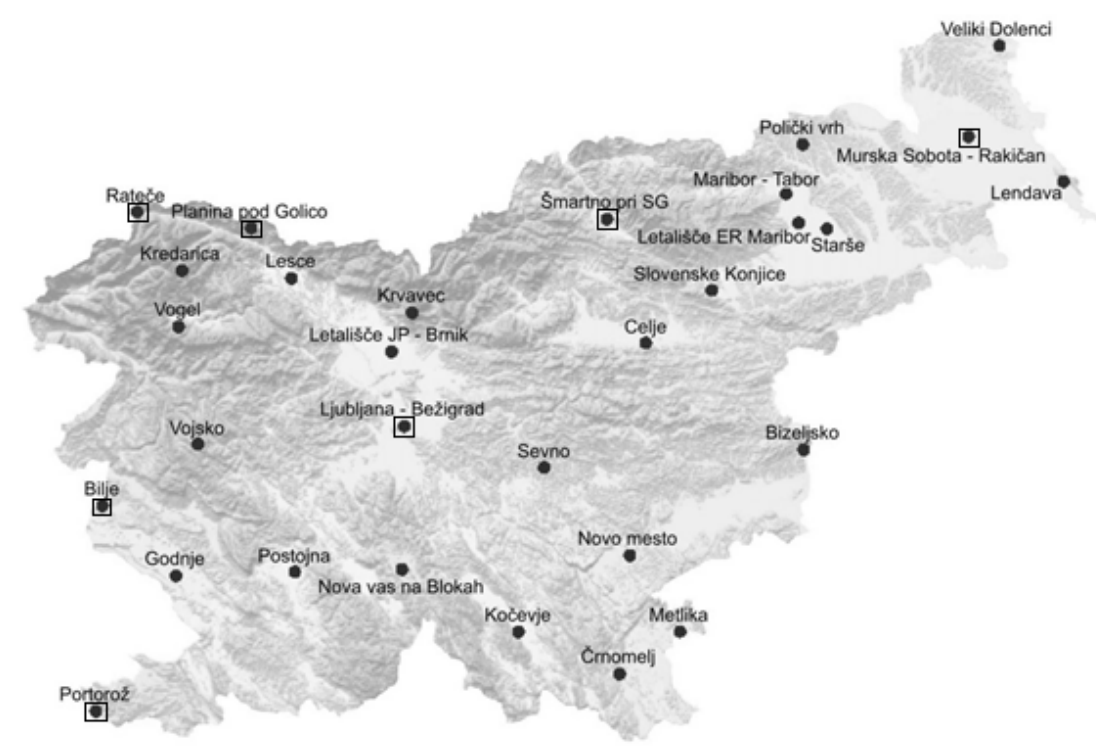

Slika 1: Lokacije analiziranih meteoroloških postaj za izračune dolžine rastne dobe in vsot efektivnih temperatur zraka ter z izjemo Vojskega in Vogla tudi za izračune sušnosti. Označene (kvadratek) so postaje, na katerih smo opravili izračune po dveh metodah (JRC in ARSO).

Figure 1: Meteorological stations used for the calculations of vegetation period duration and sums of effective air temperatures and without Vojsko and Vogel also for the calculations of dryness. Calculations using both methods (JRC and ARSO) were done on marked stations (square).

Velik del obdelave je bil namenjen pregledu podatkov, saj so za analize potrebni 30-letni nizi brez manjkajočih vrednosti za čim več meteoroloških postaj po Sloveniji. Za analizo dveh različnih izračunov dolžine rastne dobe smo izbrali sedem postaj (označene s kvadratkom na sliki 1): Planina pod Golico (956 m n.v.), Rateče - Planica (864 m n.v.), Bilje (55 m n.v.), Ljubljana Bežigrad (299 m n.v.), Šmartno pri Slovenj Gradcu (444 m n.v.), Murska Sobota - Rakičan 
(187 m n.v.) in Portorož - letališče (2 m n.v.), ki pa ima krajši niz podatkov (1989-2010) in je zato v preglednicah označen $\mathrm{z} *$. Za izračune dolžine rastne dobe po JRC in vsot efektivnih temperatur zraka smo uporabili še dodatnih 23 postaj (slika 1), tudi višje ležeče (nad 1000 m nadmorske višine), kjer večinoma ni več kmetijskih površin, a so nam služile za vpogled $\mathrm{v}$ spreminjanje vrednosti obravnavanih spremenljivk $\mathrm{z}$ višino. Kredarico smo iz poročila nato izločili, ker leži $\mathrm{V}$ visokogorju. $\mathrm{Za}$ izračune meteorološke vodne bilance je bil uporabljen enak nabor postaj, le brez Vojskega in Vogla.

\section{REZULTATI Z DISKUSIJO}

\subsection{Nastop spomladanskega in jesenskega} temperaturnega praga

Časovni vrsti dneva nastopa spomladanskega in jesenskega temperaturnega praga $\mathrm{z}$ izračunanimi drsečimi sredinami reda 10 za Ljubljano (slika 2) odražata stanje na vseh sedmih izbranih postajah in po pričakovanjih tudi $\mathrm{v}$ veliki meri na vseh obravnavanih postajah. Drseče sredine reda 10 nakazujejo močno prisoten trend, kar pomeni, da 30-letno povprečje ne predstavlja dobrega opisa stanja, a mora biti vseeno uporabljeno kot del zahtevane metodologije.

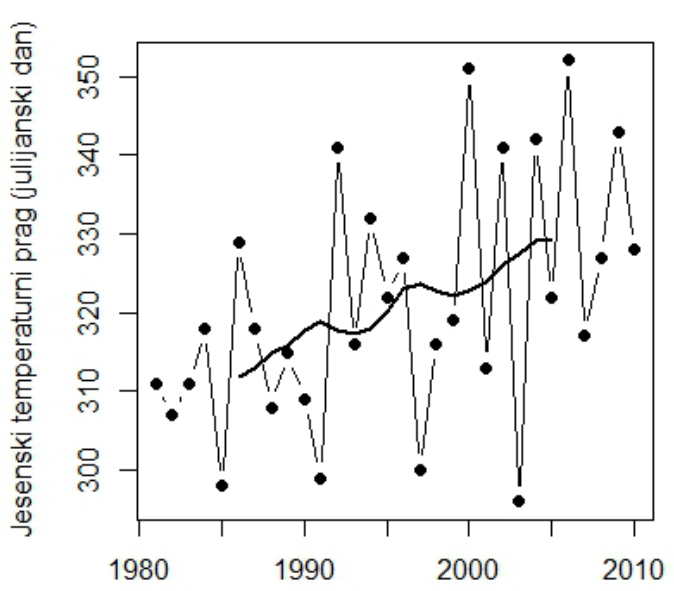

Slika 2: Časovna vrsta (•-) ter drseče sredine reda 10 (črna črta) dneva nastopa spomladanskega (levo) in jesenskega temperaturnega praga (desno), izračunanega po metodi JRC, v Ljubljani za obdobje 1981-2010

Figure 2: Time series $(\bullet-)$ and $10^{\text {th }}$ order (black line) moving averages of day of the occurence of spring (left) and autumn threshold (right), using JRC method for Ljubljana for the period 1981-2010

Za sedem izbranih postaj smo prikazali povprečni dan nastopa spomladanskega in jesenskega praga po obeh metodah $\mathrm{z}$ označenim variacijskim razmikom. Pri tem vmesno polje predstavlja povprečno dolžino rastne dobe (slika 3 ). 


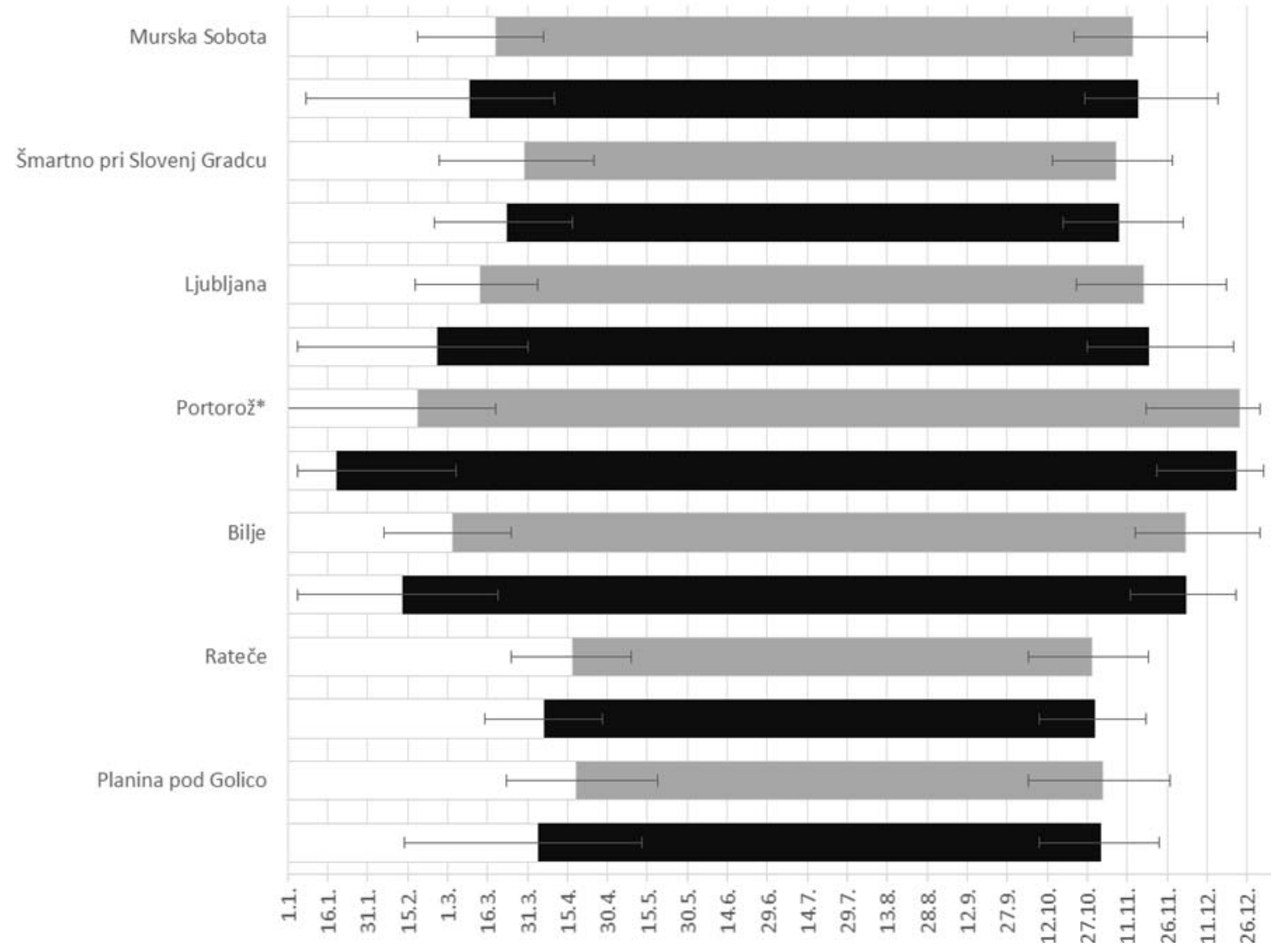

Slika 3: Povprečni dan nastopa in variacijski razmik spomladanskega in jesenskega praga (osenčena je povprečna dolžina rastne dobe) za izbrane postaje za obdobje 1981-2010 po metodi JRC (črno) in ARSO (sivo) (*krajši niz podatkov)

Figure 3: Average day of the occurence and variability range of spring and autumn threshold (average vegetation period duration is shaded) for chosen stations for the period 1981-2010 using JRC (black) and ARSO method (grey) (*shorter data set)

$\mathrm{V}$ povprečju je spomladanski prag po JRC najhitreje nastopil v Portorožu, 19. januarja, na začetku februarja $v$ Biljah ter ob koncu februarja $\mathrm{v}$ Ljubljani, na začetku marca v Murski Soboti in ob koncu marca v Šmartnem pri Slovenj Gradcu ter v prvih dneh aprila $\mathrm{v}$ Ratečah in na Planini pod Golico. Spomladanski prag je v povprečju po JRC na vseh postajah nastopil prej kot po metodi ARSO. To lahko pripišemo januarskim otoplitvam v letih od 1981 do 1986, 1991, 1993, 1994, od 1996 do 1998, od 2003 do 2005 ter od 2008 do 2010 in februarski otoplitvi v letu 1987, ki jih metoda JRC ne izloči.

Predvsem je očitna razlika $\mathrm{v}$ nastopu najzgodnejšega spomladanskega praga, saj je po metodi JRC ta $\mathrm{v}$ Biljah in Ljubljani nastopil že 5. januarja, v Murski Soboti 8. januarja in na Planini pod Golico 14. februarja, po ARSO pa v istem vrstnem redu 6. februarja, 18. februarja, 19. februarja in 23. marca, torej so zamiki vsaj enomesečni. V Portorožu je po metodi ARSO najzgodnejši prag nastopil že 1 . januarja, po JRC pa 5. januarja. Najkasneje je bil po metodi ARSO dosežen v letu 1992, 19. marca, a je bilo podobnih let še kar nekaj. V Ratečah in na Planini pod Golico pa je bil zaradi večje nadmorske višine prestop spomladanskega praga nekoliko zamaknjen, najbolj zgoden je bil $\mathrm{v}$ marcu, najkasnejši pa $\mathrm{v}$ maju. Prav posebno je bilo $\mathrm{v}$ Portorožu leto 1988, ko so bile povprečne dnevne temperature zraka z izjemo le nekaj dni vse leto nad $5{ }^{\circ} \mathrm{C}$, tako da se je rastna doba po metodi ARSO teoretično začela 1. januarja, končala pa 31. decembra, praktično pa se je začela leta 1987 in nadaljevala $\mathrm{v}$ leto 1989. 
Jesenski prag je $\mathrm{v}$ povprečju nastopil po obeh metodah ob približno istem času. Najzgodneje je nastopil $\mathrm{v}$ celotnem obravnavanem obdobju po metodi JRC v Ratečah in na Planini pod Golico 9. oktobra (po ARSO 5. oktobra), v Šmartnem pri Slovenj Gradcu, Murski Soboti in Ljubljani v drugi polovici oktobra ter v Biljah 12. novembra (po ARSO 14. novembra) in $\mathrm{v}$ Portorožu šele 22. novembra (po ARSO 18. novembra). Najkasneje $v$ celotnem obdobju pa je jesenski prag v Ljubljani, Biljah in Portorožu nastopil $\mathrm{v}$ drugi polovici decembra, v Šmartnem pri Slovenj Gradcu in Murski Soboti v prvi polovici decembra ter že v drugi polovici novembra $v$ Ratečah in na Planini pod Golico.

Glede na že opaženo segrevanje ozračja, ki se odraža tudi pri padajočih drsečih sredinah spomladanskega in naraščajočih jesenskega temperaturnega praga, ter ob pričakovanem nadaljnjem segrevanju ozračja (Prihodnje spremembe ..., 2014), se bo pojav, da se rastna doba ne prekine, pogosteje dogajal ne samo na
Primorskem, ampak tudi na drugih območjih. Podobno po modelskih napovedih ob koncu stoletja pričakujejo celo za južnejše predele Finske (Ruosteenoja in sod., 2010).

\subsection{Dolžina rastne dobe in vsote efektivnih temperatur zraka}

Pri prikazu časovne vrste dolžine rastne dobe (slika 4 levo) se je za izbrane postaje izkazalo, da prisotnost trenda ni tako očitna kot pri temperaturnih pragovih, po drugi strani pa se je za vsote efektivnih temperatur zraka (slika 4 desno) nazorno pokazala prisotnost naraščajočega trenda.

Predvsem za vsote efektivnih temperatur zraka velja enako kot za temperaturne pragove. Povprečje se zaradi trenda $\mathrm{v}$ obravnavanem obdobju spreminja. Kljub temu pa moramo za potrebe določanja OMD obravnavati povprečja, a hkrati opozarjamo, da se razmere spreminjajo in bi bilo zato potrebno metodologijo spremeniti.

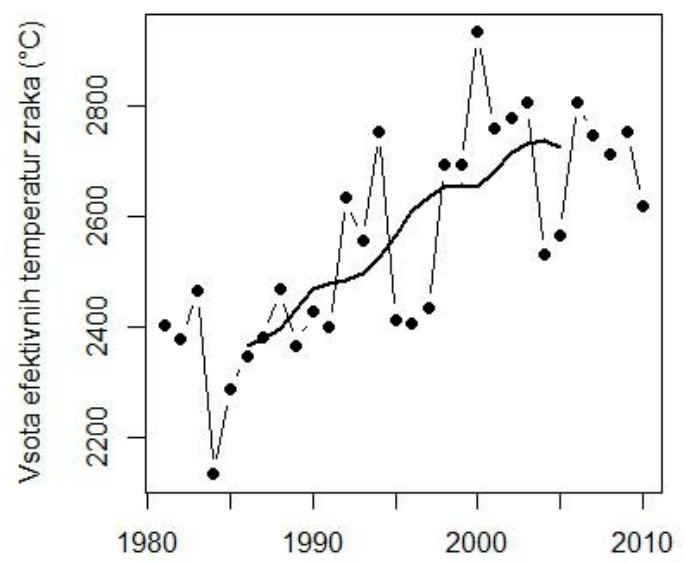

Slika 4: Časovna vrsta $(\bullet-)$ ter drseče sredine reda 10 (črna črta) letne dolžine rastne dobe (levo) in vsote efektivnih temperatur zraka (desno), izračunanih po metodi JRC, v Ljubljani za obdobje 1981-2010

Figure 4: Time series $(\bullet-)$ and $10^{\text {th }}$ order (black line) moving averages of vegetation period duration (left) and sum of effective air temperatures (right), using JRC method for Ljubljana for the period 1981-2010

Povprečne dolžine rastne dobe (preglednica 1) so po metodi ARSO od 195 dni v Ratečah do 307 dni v Portorožu, po metodi JRC pa od 208 dni v Ratečah do 338 dni v Portorožu. Razlika v metodologiji torej prispeva $\mathrm{k}$ precej različnim rezultatom. Standarne napake (preglednica 1) in koeficienti variacije so primerljivi, najbolj izstopata po metodi JRC Ljubljana $\mathrm{z}$ največjim in Portorož $\mathrm{z}$ najmanjšim koeficientom variacije. 
Preglednica 1: Povprečne dolžine rastne dobe (povp) in standardne napake (se) za izbrane postaje za obdobje 19812010 po metodah JRC in ARSO

Table 1: Average vegetation period duration (povp) and standard errors (se) for chosen stations for the period 19812010 using JRC and ARSO method

\begin{tabular}{|c|c|c|c|c|c|c|c|}
\hline & $\begin{array}{l}\text { Planina } \\
\text { pod Golico } \\
\text { (št. dni) }\end{array}$ & $\begin{array}{l}\text { Rateče } \\
\text { (št. dni) }\end{array}$ & $\begin{array}{l}\text { Bilje } \\
\text { (št. dni) }\end{array}$ & $\begin{array}{l}\text { Portorož* } \\
\text { (št. dni) }\end{array}$ & $\begin{array}{l}\text { Ljubljana } \\
\text { (št. dni) }\end{array}$ & $\begin{array}{l}\text { Šmartno pri } \\
\text { Slovenj Gradcu } \\
\text { (̌̌t. dni) }\end{array}$ & $\begin{array}{l}\text { Murska } \\
\text { Sobota } \\
\text { (št. dni) }\end{array}$ \\
\hline JRC-povp & 211 & 208 & 293 & 338 & 266 & 229 & 251 \\
\hline JRC-se & 3,6 & 2,8 & 5,5 & 3,1 & 5,8 & 3,5 & 4,6 \\
\hline ARSO-povp & 198 & 195 & 276 & 307 & 249 & 222 & 239 \\
\hline ARSO-se & 3,6 & 2,9 & 3,3 & 5,0 & 3,8 & 3,8 & 3,6 \\
\hline
\end{tabular}

*krajši niz podatkov (*shorter data set)

Preglednica 2: Povprečne vsote efektivnih temperatur zraka nad pragom $5^{\circ} \mathrm{C}$ (povp) in standardne napake (se) po metodah JRC in ARSO za izbrane postaje za obdobje 1981-2010

Table 2: Average sums of effective air temperatures over the threshold $5{ }^{\circ} \mathrm{C}$ (povp) and standard errors (se) for chosen stations for the period 1981-2010 using JRC and ARSO method

\begin{tabular}{lccccccc}
\hline & $\begin{array}{l}\text { Planina } \\
\text { pod Golico } \\
\left({ }^{\circ} \mathrm{C}\right)\end{array}$ & $\begin{array}{l}\text { Rateče } \\
\left({ }^{\circ} \mathrm{C}\right)\end{array}$ & $\begin{array}{l}\text { Bilje } \\
\left({ }^{\circ} \mathrm{C}\right)\end{array}$ & $\begin{array}{l}\text { Portorož } \\
\left({ }^{\circ} \mathrm{C}\right)\end{array}$ & $\begin{array}{l}\text { Ljubljana } \\
\left({ }^{\circ} \mathrm{C}\right)\end{array}$ & $\begin{array}{l}\text { Śmartno pri } \\
\text { Slovenj Gradcu } \\
\left({ }^{\circ} \mathrm{C}\right)\end{array}$ & $\begin{array}{l}\text { Murska } \\
\text { Sobota } \\
\left({ }^{\circ} \mathrm{C}\right)\end{array}$ \\
\hline JRC-povp & 1444 & 1546 & 2885 & 3237 & 2554 & 2001 & 2402 \\
JRC-se & 21,6 & 22,1 & 40,0 & 27,8 & 35,1 & 24,1 & 31,8 \\
ARSO- & 1446 & 1546 & 2878 & 3218 & 2547 & 2002 & 2396 \\
povp & 21,5 & 22,2 & 38,2 & 28,3 & 34,9 & 24,5 & 31,0 \\
JRC-se & & & & & & & \\
\hline
\end{tabular}

*krajši niz podatkov (*shorter data set)

Povprečna vsota efektivnih temperatur zraka nad pragom $5{ }^{\circ} \mathrm{C}$ (preglednica 2) je na Planini pod Golico $\left(1444{ }^{\circ} \mathrm{C}\right.$ oz. $\left.1446{ }^{\circ} \mathrm{C}\right)$ in $\mathrm{v}$ Ratečah $\left(1546^{\circ} \mathrm{C}\right)$ pod pragom $\mathrm{JRC}$, ki znaša $1500^{\circ} \mathrm{C}$. Na ostalih postajah so povprečne vsote nad to mejo, in sicer od $2001{ }^{\circ} \mathrm{C}$ (po JRC oz. $2002{ }^{\circ} \mathrm{C}$ po ARSO) v Šmartnem pri Slovenj Gradcu do $3237^{\circ} \mathrm{C}$ (po JRC oz. $3218^{\circ} \mathrm{C}$ po ARSO) v Portorožu. Razlike v povprečjih med metodama niso velike, standardne napake so povsem primerljive.

Za potrebe določanja OMD smo po metodi JRC za vse obravnavane postaje določili, kdaj je dosežen spomladanski in jesenski temperaturni prag, nato pa smo izračunali dolžino rastne dobe ter vsoto efektivnih povprečnih dnevnih temperatur zraka ter 30-letna povprečja teh vrednosti. Meja, ki je s strani Evropske komisije določena za vključitev v OMD, je presežena za povprečno dolžino rastne dobe le na Krvavcu, za povprečno vsoto efektivnih temperatur zraka pa na Krvavcu, Planini pod Golico, Vojskem in Voglu (preglednica 3). Vse te postaje ležijo nad $1000 \mathrm{~m}$ nadmorske višine.

Ker samo povprečje ne nudi zadostne informacije o razmerah, je variabilnost znotraj 30-letnega obdobja upoštevana tako, da se območje uvrsti v OMD tudi v primeru, ko je 7 od 30 let na postaji pod pragom $180 \mathrm{dni}$ oziroma pod pragom $1500{ }^{\circ} \mathrm{C}$ (zadnja stolpca $\mathrm{v}$ preglednici 3). Po tem kriteriju se dodatno uvrsti v OMD območja le postaja Rateče.

$\mathrm{Na}$ evropski ravni so izračune za temperaturni kriterij za OMD za obdobje 1975-2004 objavili Eliasson in sod. (2010). Pokazali so, da večina Evrope z izjemo severa in izrazito gorskega sveta ne zadošča temperaturnemu kriteriju za OMD. Enako se je pokazalo tudi $\mathrm{v}$ naših izračunih za Slovenijo. 
Preglednica 3: Povprečni nastop spomladanskega in jesenskega praga, povprečna dolžina rastne dobe in povprečna vsota efektivnih temperatur zraka za temperaturni prag $5^{\circ} \mathrm{C}$ za obdobje $1981-2010$ po metodi JRC. Krepko so označene postaje in vrednosti, ki so pod mejo $1500^{\circ} \mathrm{C}$, ki definira območje z OMD. Na desni je število let (od obravnavanih 30), v katerih je dolžina rastne dobe oz. vsota efektivnih temperatur zraka pod pragom za OMD. Ležeče so označene vrednosti večje od 7 , kar je meja za uvrstitev med OMD.

Table 3: Average occurence of spring and autumn threshold, average vegetation period duration and average sum of effective air temperatures with the threshold of $5^{\circ} \mathrm{C}$ for the period 1981-2010 using JRC method. Values below the threshold $1500{ }^{\circ} \mathrm{C}$ for less favoured areas (LFA) are marked bold. On the right is the number of years (out of 30 ), in which is the vegetation period duration or the sum of effective air temperatures below the threshold for LFA. Values over 7, which is the threshold for LFA, are marked italic.

\begin{tabular}{|c|c|c|c|c|c|c|}
\hline Postaja & $\begin{array}{l}\text { Spomladanski } \\
\text { prag } 5^{\circ} \mathrm{C} \\
\text { (datum) }\end{array}$ & $\begin{array}{c}\text { Jesenski } \\
\text { prag } 5{ }^{\circ} \mathrm{C} \\
\text { (datum) }\end{array}$ & $\begin{array}{r}\text { Dolžina } \\
\text { rastne dobe } \\
(\text { dni })\end{array}$ & $\begin{array}{r}\text { Vsota } \\
\text { efektivnih } \\
\text { temperatur } \\
\text { zraka }\left({ }^{\circ} \mathrm{C}\right)\end{array}$ & $\begin{array}{r}\text { Št. let pod } \\
\text { pragom } \\
180 \text { dni }\end{array}$ & $\begin{array}{r}\text { Št. let pod } \\
\text { pragom } \\
1500{ }^{\circ} \mathrm{C}\end{array}$ \\
\hline Krvavec & 4.5 . & 7.10 . & 156 & 761 & 25 & 30 \\
\hline Brnik - letališče & 18.3. & 11.11. & 238 & 2172 & 0 & 0 \\
\hline Planina pod Golico & 4.4 . & 1.11 & 211 & 1443 & 1 & 20 \\
\hline Rateče & 6.4. & 30.10 . & 208 & 1546 & 1 & 12 \\
\hline Vojsko & 3.4 . & 31.10 . & 211 & 1455 & 2 & 20 \\
\hline Bilje & 13.2 . & 3.12 . & 293 & 2885 & 0 & 0 \\
\hline Godnje & 15.2 . & 27.11 . & 285 & 2582 & 0 & 0 \\
\hline Postojna & 8.3 . & 13.11 . & 250 & 2025 & 0 & 0 \\
\hline Nova vas na Blokah & 20.3 . & 5.11 & 230 & 1718 & 1 & 1 \\
\hline Kočevje & 10.3 & 9.11 & 244 & 2025 & 0 & 0 \\
\hline Ljubljana - Bežigrad & 26.2 . & 19.11. & 266 & 2554 & 0 & 0 \\
\hline Sevno & 21.2 & 13.11. & 266 & 2182 & 0 & 0 \\
\hline Bizeljsko & 2.3 . & 18.11. & 260 & 2478 & 0 & 0 \\
\hline Novo mesto & 21.2 & 17.11 . & 269 & 2469 & 0 & 0 \\
\hline Črnomelj & 27.2 . & 18.11 . & 264 & 2598 & 0 & 0 \\
\hline Celje & 5.3 . & 16.11 . & 256 & 2367 & 0 & 0 \\
\hline Slovenske Konjice & 16.2 . & 18.11. & 275 & 2378 & 0 & 0 \\
\hline Starše & 28.2 . & 16.11 . & 261 & 2450 & 0 & 0 \\
\hline Maribor - Tabor & 2.3 . & 17.11 . & 260 & 2505 & 0 & 0 \\
\hline Maribor - letališče & 6.3 . & 16.11. & 255 & 2386 & 0 & 0 \\
\hline $\begin{array}{l}\text { Šmartno pri Slovenj } \\
\text { Gradcu }\end{array}$ & 23.3 . & 8.11 & 229 & 2001 & 0 & 0 \\
\hline Polički vrh & 15.3. & 12.11 . & 242 & 2230 & 0 & 0 \\
\hline Lendava & 23.2 . & 16.11 . & 266 & 2504 & 0 & 0 \\
\hline $\begin{array}{l}\text { Murska Sobota - } \\
\text { Rakičan }\end{array}$ & 9.3. & 15.11. & 251 & 2402 & 0 & 0 \\
\hline Veliki Dolenci & 28.2 . & 15.11 . & 261 & 2378 & 0 & 0 \\
\hline Lesce & 22.3 & 11.11. & 234 & 2012 & 0 & 0 \\
\hline Metlika & 16.2. & 18.11. & 275 & 2580 & 0 & 0 \\
\hline Vogel & 20.4 & 20.10 . & 184 & 981 & 12 & 28 \\
\hline Portorož* & 22.1. & 20.12 . & 332 & 3205 & 0 & 0 \\
\hline
\end{tabular}

*krajši niz podatkov (shorter data set)

\subsection{Kazalec sušnosti in meteorološka vodna bilanca}

Kazalec sušnosti $A I$ za postajo Murska Sobota Rakičan je na letni ravni 1,0, za vegetacijsko obdobje 0,8 , za postajo Rateče pa na letni ravni $2,4, \quad \mathrm{v}$ vegetacijskem obdobju pa 1,6. Po priporočenem kazalcu sušnosti $A I$ se torej noben del Slovenije ne uvršča pod določeni prag za OMD $(0,5)$. Vrednosti so visoko nad pragom, zato lahko predpostavljamo, da je v vsej Sloveniji AI nad podano mejo in ga na ostalih postajah nismo analizirali. 

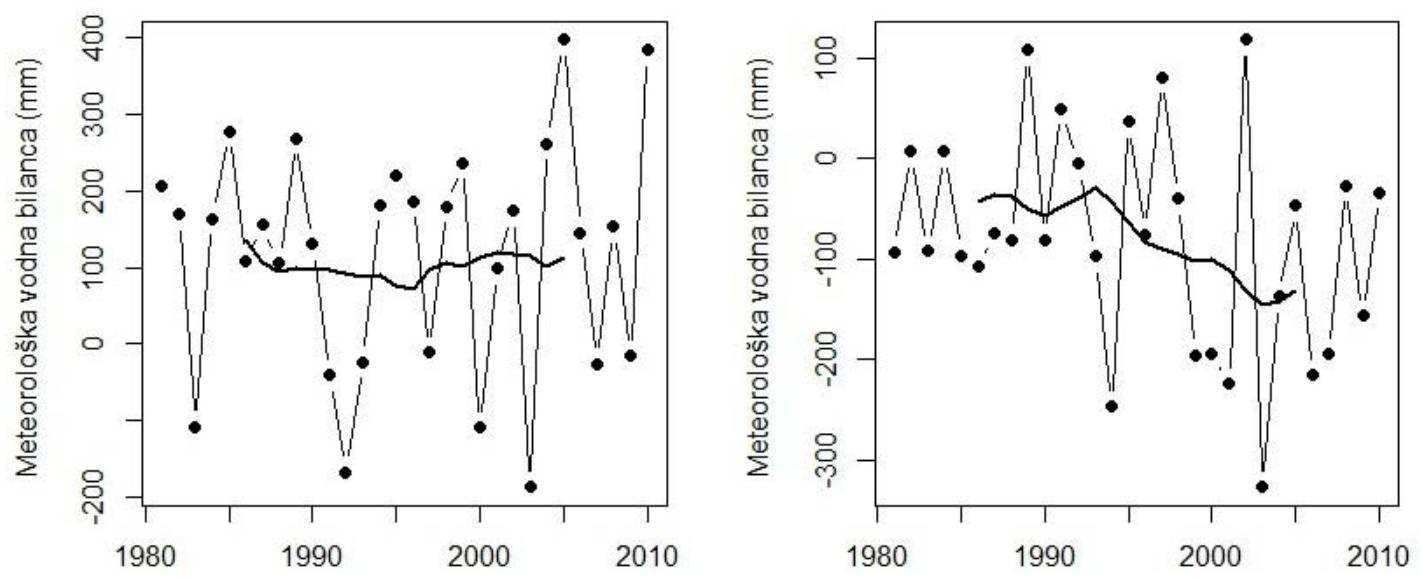

Slika 5: Časovna vrsta $(\bullet-)$ ter drseče sredine reda 10 (̌̌rna črta) vegetacijske meteorološke vodne bilance v Ljubljani (levo) in Biljah (desno) za obdobje 1981-2010, izračunanih po metodi JRC

Figure 5: Time series $(\bullet-)$ and $10^{\text {th }}$ order (black line) moving averages of meteorological water balance in vegetation period for Ljubljana (left) and Bilje (right) for the period 1981-2010, using JRC method

Vendar pa so izračuni že pred letom 2010 kazali na povečevanje vodnega primanjkljaja in s tem tudi števila sušnih dni $\mathrm{v}$ vegetacijskem obdobju (Pogačar in Kajfež-Bogataj, 2008). Kot prikazuje Sušnikova (2014), je predvsem po letu 2000 povprečna poletna (junij-avgust) meteorološka vodna bilanca (razlika med količino padavin in potencialno evapotranspiracijo) v več letih izrazito negativna, kar lahko predstavlja sušo na državni ravni. Zato smo v projektu, da bi bolje upoštevali dejansko stanje v Sloveniji, naredili tudi izračune meteorološke vodne bilance. Pri tem negativna vodna bilanca pomeni, da je v izbranem obdobju padlo manj padavin, kot pa je izhlapelo vode iz tal in referenčne rastline. Ne pomeni pa negativna vodna bilanca še nujno sušnega stanja, saj je pomembno, kako negativna je in koliko časa primanjkljaj traja. Tako tudi povprečna negativna vodna bilanca ne označuje suše.

Tudi za časovne vrste meteorološke vodne bilance $\mathrm{v}$ vegetacijskem obdobju nas je zanimalo, kakšen trend lahko ocenimo $\mathrm{z}$ drsečimi sredinami. Za izbranih sedem postaj se je pokazalo, da ne gre za izrazite trende kot pri temperaturnih pragovih in vsotah. V Ljubljani (slika 5 levo) se, na primer, trend ne kaže, v Biljah (slika 5 desno) se nakazuje negativni trend, v Šmartnem pri Slovenj Gradcu celo pozitivni. Zato moramo biti tudi pri obravnavi te spremenljivke previdni in upoštevati, da je potrebno izračune povprečij že čez nekaj let ponoviti.

Predstavljeni so rezultati meteorološke vodne bilance za vegetacijsko obdobje (preglednica 4). Povprečna meteorološka vodna bilanca je negativna na postajah (označene krepko $\mathrm{v}$ preglednici 4): Bizeljsko, Starše, Maribor - Tabor, Maribor - letališče, Lendava, Murska Sobota Rakičan, Portorož. Mediana pa je negativna za Bilje in Metliko (prav tako označeni krepko). Od naštetih je najmanjša povprečna vrednost na postaji Portorož (-320 mm), sledijo Veliki Dolenci ($174 \mathrm{~mm})$, Murska Sobota - Rakičan $(-115 \mathrm{~mm})$ in Lendava $(-109 \mathrm{~mm})$. Na teh štirih postajah (v preglednici 4 osenčene) je negativen še 75 . percentil vodne bilance za obravnavano obdobje, kar pomeni, da je bila vodna bilanca vsaj $\mathrm{v}$ 75 odstotkih let negativna.

Velike povprečne vrednosti vodne bilance so pričakovano na višje ležečih postajah: Planina pod Golico (452 mm), Krvavec (364 mm) in Rateče (311 mm). 
Preglednica 4: Meteorološka vodna bilanca (najmanjša in največja vrednost, 25., 50. in 75. percentil in povprečne vrednosti; v mm) ter delež analiziranih podatkov za obdobje 1981-2010. Krepko so označene postaje z negativnimi vrednostmi povprečja ali mediane; osenčene so postaje, pri katerih je negativna še vrednost vodne bilance pri 75. percentilu.

Table 4: Meteorological water balance (minimum and maximum, $25^{\text {th }}, 50^{\text {th }}$ and $75^{\text {th }}$ percentile, and average values; in $\mathrm{mm}$ ) and the proportion of analyzed data for the period 1981-2010. Negative values of the average or median are marked bold; negative values of $75^{\text {th }}$ percentile are shaded.

\begin{tabular}{|c|c|c|c|c|c|c|c|}
\hline Postaja & $\begin{array}{l}\text { Min } \\
(\mathrm{mm})\end{array}$ & $\begin{array}{c}25 . \\
\text { percentil } \\
(\mathrm{mm})\end{array}$ & $\begin{array}{c}\text { Mediana } \\
(\mathrm{mm})\end{array}$ & $\begin{array}{c}75 . \\
\text { percentil } \\
(\mathrm{mm})\end{array}$ & $\begin{array}{l}\text { Maks } \\
(\mathrm{mm})\end{array}$ & $\begin{array}{c}\text { Povprečje } \\
(\mathrm{mm})\end{array}$ & $\begin{array}{c}\text { Delež } \\
\text { analiziranih } \\
\text { podatkov }\end{array}$ \\
\hline Krvavec & $-26,3$ & 228,0 & 358,0 & 541,9 & 636,2 & 363,9 & $96 \%$ \\
\hline Brnik - letališče & $-239,9$ & 50,8 & 213,7 & 290,7 & 470,5 & 157,8 & $100 \%$ \\
\hline Planina pod Golico & 158,1 & 360,0 & 445,0 & 544,9 & 778,4 & 452,0 & $99 \%$ \\
\hline Rateče & 45,5 & 258,1 & 312,2 & 392,3 & 466,8 & 311,2 & $100 \%$ \\
\hline Bilje & $-448,5$ & $-89,1$ & $-11,0$ & 169,7 & 388,2 & 17,2 & $100 \%$ \\
\hline Godnje & $-349,3$ & $-25,2$ & 79,4 & 199,6 & 512,6 & 86,9 & $100 \%$ \\
\hline Postojna & $-233,0$ & 39,8 & 226,2 & 307,4 & 452,4 & 171,3 & $100 \%$ \\
\hline Nova vas na Blokah & $-109,6$ & 145,3 & 269,5 & 348,4 & 560,2 & 244,1 & $100 \%$ \\
\hline Kočevje & $-179,0$ & 113,8 & 188,4 & 275,4 & 378,9 & 175,4 & $99 \%$ \\
\hline Ljubljana - Bežigrad & $-187,7$ & $-15,1$ & 154,9 & 200,7 & 397,5 & 117,1 & $100 \%$ \\
\hline Sevno & $-146,9$ & 73,6 & 139,9 & 201,1 & 369,7 & 133,2 & $99 \%$ \\
\hline Bizeljsko & $-410,1$ & $-102,4$ & $-13,7$ & 82,6 & 315,5 & $-35,0$ & $100 \%$ \\
\hline Novo mesto & $-398,8$ & $-22,5$ & 27,8 & 129,0 & 416,9 & 47,2 & $100 \%$ \\
\hline Črnomelj & $-274,6$ & $-26,5$ & 103,4 & 186,5 & 526,3 & 83,8 & $96 \%$ \\
\hline Celje & $-385,0$ & 22,1 & 60,9 & 112,8 & 326,0 & 46,0 & $100 \%$ \\
\hline Slovenske Konjice & $-363,6$ & $-40,4$ & 70,8 & 110,9 & 294,5 & 26,2 & $99 \%$ \\
\hline Starše & $-497,1$ & $-70,9$ & $-26,1$ & 43,1 & 194,4 & $-48,4$ & $100 \%$ \\
\hline Maribor - Tabor & $-388,1$ & $-82,5$ & $-32,8$ & 75,9 & 355,6 & $-15,2$ & $100 \%$ \\
\hline Maribor - letališče & $-403,4$ & $-116,8$ & $-59,1$ & 32,5 & 234,7 & $-67,2$ & $97 \%$ \\
\hline Šmartno pri SG & $-84,9$ & 110,4 & 152,3 & 270,4 & 364,4 & 169,2 & $100 \%$ \\
\hline Polički vrh & $-237,3$ & $-24,1$ & 35,8 & 193,4 & 325,3 & 71,8 & $100 \%$ \\
\hline Lendava & $-390,1$ & $-165,3$ & $-104,4$ & $-37,3$ & 130,6 & $-108,9$ & $100 \%$ \\
\hline $\begin{array}{l}\text { Murska Sobota - } \\
\text { Rakičan }\end{array}$ & $-416,1$ & $-176,8$ & $-122,0$ & $-34,2$ & 142,9 & $-115,3$ & $100 \%$ \\
\hline Veliki Dolenci & $-500,8$ & $-235,9$ & $-154,8$ & $-67,4$ & 109,8 & $-174,0$ & $100 \%$ \\
\hline Lesce & $-79,2$ & 147,5 & 220,9 & 314,2 & 478,8 & 219,3 & $100 \%$ \\
\hline Metlika & $-298,4$ & $-91,6$ & $-1,0$ & 138,1 & 315,9 & 13,2 & $98 \%$ \\
\hline Portorož* & $-574,9$ & $-436,0$ & $-343,0$ & $-257,4$ & 47,1 & $-319,9$ & $62 \%$ \\
\hline
\end{tabular}

*krajši niz podatkov (shorter data set)

Povprečje vegetacijske vodne bilance je bilo v obdobju 1981-2010 glede na obdobje 1971-2000 na skoraj vseh lokacijah manjše oziroma bolj negativno (slika 6). Najbolj negativna odstopanja so v Biljah, kar 94 mm, v Postojni 51 mm, v Celju
$38 \mathrm{~mm}$, v Ratečah $37 \mathrm{~mm}$ in v Velikih Dolencih $32 \mathrm{~mm}$. Za rastline bolj ugodna pa je vodna bilanca postala v Šmartnem pri Slovenj Gradcu, Mariboru, na Poličkem vrhu in Planini pod Golico. 


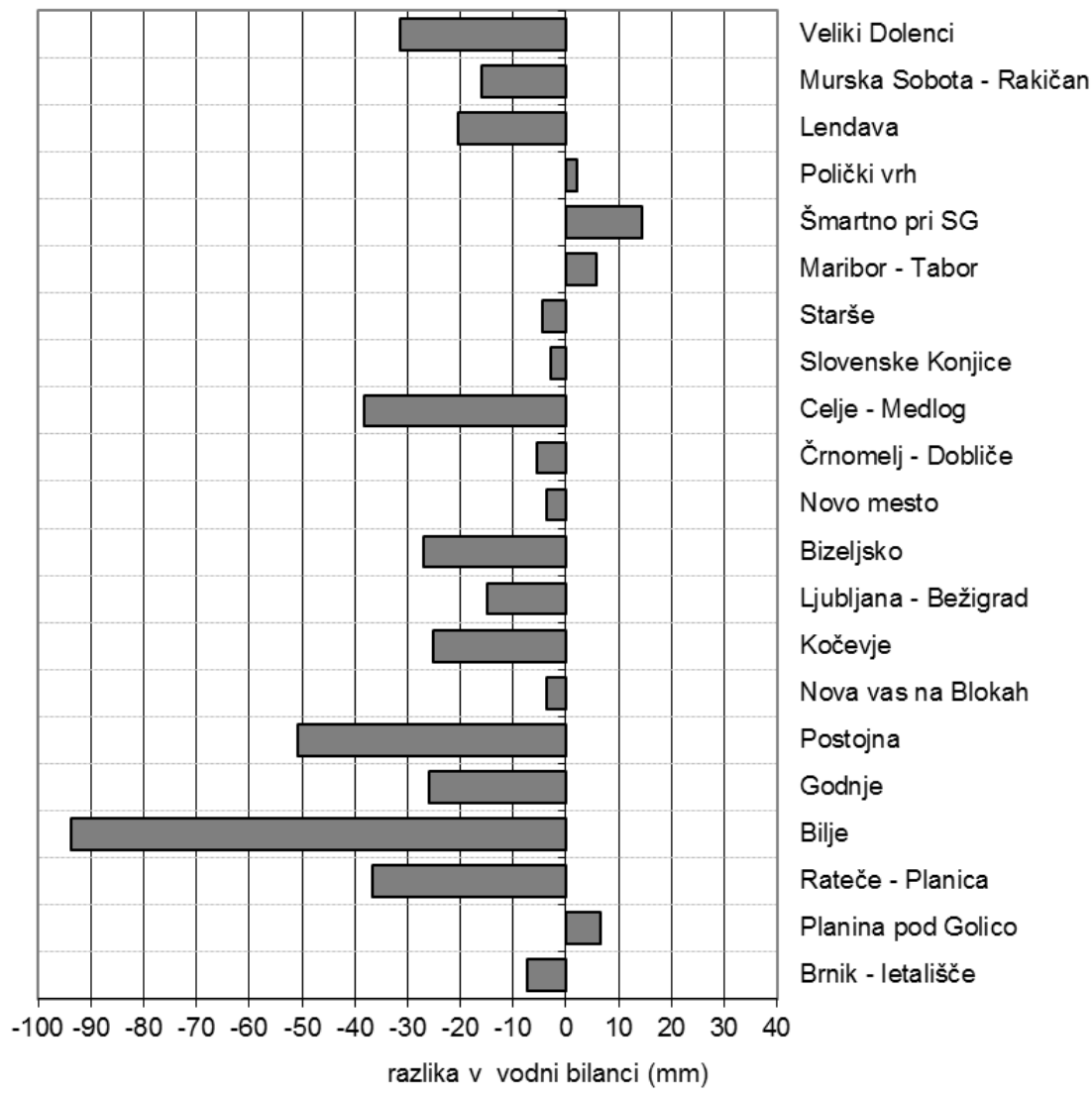

Slika 6: Odstopanja povprečne vegetacijske meteorološke vodne bilance za obdobje 1981-2010 glede na obdobje 1971-2000

Figure 6: Deviations of average vegetation meteorological water balance for the period 1981-2010 with regard to the period 1971-2000

\section{SKLEPI}

Metodi ARSO in JRC za izračun nastopa temperaturnih pragov se med seboj razlikujeta, kar se je pokazalo pri povprečnih dolžinah rastnih dob na sedmih izbranih postajah, razlike v povprečnih vsotah efektivnih temperatur zraka pa so bile zelo majhne. Ker je bila $\mathrm{z}$ metodo drsečih sredin prikazana prisotnost trenda $\mathrm{v}$ obravnavanih časovnih vrstah, nam povprečja ne dajo dovolj dobre informacije o vrednostih spremenljivk v 30letnem obdobju, hkrati pa tudi niso primerna za dobro medsebojno primerjavo metod. Kljub temu morajo biti izračuni za Evropsko komisijo pripravljeni po metodi JRC, za določanje OMD moramo pripraviti povprečja za 30-letno obdobje, ne glede na trend. Pokazalo se je, da so po temperaturnem kriteriju pod pragom le vrednosti na meteoroloških postajah $\mathrm{v}$ hribovitem svetu, nad ali blizu $1000 \mathrm{~m}$ nadmorske višine, najnižja uvrščena meteorološka postaja je $\mathrm{v}$ Ratečah. Po kriteriju aridnega podnebja, določenim z indeksom $A I$, se Slovenija ne uvršča med OMD.

Pri odločitvah moramo torej upoštevati podnebne spremembe, predvsem naraščanje temperature zraka, ki lahko povzroči nove razmere $\mathrm{v}$ kmetijstvu. To se kaže že $\mathrm{v}$ sedanji analizi $\mathrm{s}$ prisotnostjo trendov. $Z$ naraščanjem temperature zraka je povezano naraščanje števila vročih in toplih dni ter upadanje števila hladnih dni. Za fenološki razvoj rastlin je ključnega pomena, da je dovolj hladnih dni, preveliko število toplih ali celo vročih dni pa deluje stresno (Kajfež-Bogataj in sod., 2010). V zadnjih letih je bilo na kmetijskih rastlinah opažene veliko škode zaradi vročinskega stresa. Pri izračunih za OMD smo zato svetovali 
izračune in upoštevanje trendov obravnavanih spremenljivk oziroma redne ponovitve izračunov.

V projektu smo po analizi podatkov in izračunih potrebnih spremenljivk nadaljevali s prostorsko interpolacijo izbranih osnovnih in izvedenih klimatskih spremenljivk. Ta lahko predstavlja problem, v kolikor so podatki dostopni za premajhno število meteoroloških postaj po Sloveniji. Upoštevati je potrebno tudi parametre, povezane z razgibanostjo reliefa $v$ Sloveniji. Naše rezultate so na Kmetijskem inštitutu Slovenije vključili v točkovalni sistem za OMD. Za pomoč pri odločanju $\mathrm{v}$ primerih, kjer stanje ni povsem jasno, smo pri temperaturnem kriteriju dodatno analizirali pojav slane, število hladnih in ledenih dni ter nastop cvetenja domače češplje, pri kriteriju aridnega podnebja in meteorološki vodni bilanci pa vroče dni in vročinski stres, saj lahko predstavljajo dodatno obremenitev pri pridelavi kmetijskih kultur v Sloveniji.

\section{ZAHVALA}

Prispevek je nastal s finančno pomočjo Ministrstva za kmetijstvo, gozdarstvo in prehrano in Javne agencije za raziskovalno dejavnost RS v okviru
Ciljnega raziskovalnega programa »Zagotovimo.si hrano za jutri«.

\section{VIRI}

Allen R.G., Pereira L.S., Smith M. 1998. Crop evapotranspiration: Guidelines for computing crop requirements. Italija, FAO, Irrigation and Drainage Paper No.56.

ARSO. 2014. Izpis podatkov in definicij iz arhiva meteoroloških podatkov.

Chmielewski F.M., Rötzer T. 2001. Response of tree phenology to climate change across Europe. Agricultural and Forest Meteorology, 108: 101-112. DOI: 10.1016/S01681923(01)00233-7

Eliasson R.J.A., Jones F., Nachtergaele D.G., Rossiter J.M. in sod. 2010. Common criteria for the redefinition of Intermediate Less Favoured Areas in the European Union. Environmental Science and Policy, 13: 766-777. DOI: 10.1016/j.envsci.2010.08.003

Golmajer M. 2013. Desezoniranje časovnih vrst. Ljubljana, Statistični urad RS: 57 str. http://www.stat.si/dokument/486/Desezoniranje_ca sovnih_vrst.pdf (23. sep. 2015)

Kajfež-Bogataj L., Pogačar T., Ceglar A., Črepinšek Z. 2010. Spremembe agroklimatskih spremenljivk v Sloveniji v zadnjih desetletjih. Acta agriculturae Slovenica, 95, 1: 97-109

Pogačar T., Kajfež-Bogataj L. 2008. Možni vplivi podnebnih sprememb na vodno bilanco tal V Sloveniji. Acta agriculturae Slovenica, 91, 2: $427-$ 441
Pogačar T., Tajnik T., Kajfež-Bogataj L. 2014. Priprava Podlage za slovenski nacionalni akcijski načrt obvladovanja suše. Ujma, 28: 223-228

Povprečna letna višina korigiranih padavin. 2014. ARSO:

http://meteo.arso.gov.si/uploads/probase/www/clim ate/image/sl/by_variable/precipitation/mean-

annual-corrected-precipitation_71-00.png (12. 12. 2014)

Prihodnje spremembe podnebja v Sloveniji. 2014. Ljubljana, Ministrstvo za okolje in prostor, Agencija RS za okolje: 3 str. http://meteo.arso.gov.si/uploads/probase/www/clim ate/PSS/scenariji/podnebni_scenariji.pdf (21. maj 2015)

Program razvoja podeželja RS za obdobje 2007-2013, Priloga 3. 2009. Ljubljana, MKGP. http://www.arhiv.mkgp.gov.si/fileadmin/mkgp.gov. si/pageuploads/PRP/dec09/Priloga_3.pdf (13. 3. 2014)

Ruosteenoja K., Räisänen J., Pirinen P. 2010. Projected changes in thermal seasons and the growing season in Finland. International Journal of Climatology, 31: 1473-1487. DOI: 10.1002/joc. 2171

Sušnik A. 2014. Zasnove kazalcev spremljanja suše na kmetijskih površinah. Doktorska disertacija. Univerza v Ljubljani, Biotehniška fakulteta, Oddelek za agronomijo: 256 str.

Sušnik A., Žust A. 2008. Definicije agrometeoroloških indikatorjev pri določanju območij $\mathrm{z}$ omejenimi

Acta agriculturae Slovenica, 107 - 1, marec 2016 
Tjaša POGAČAR in sod.

možnostmi pridelovanja (OMD). Novi izzivi v poljedelstvu 2008, 338-344

Updated common biophysical criteria to define natural constraints for agriculture in Europe. Definition and scientific justification for the common biophysical criteria. 2012. Van Orshoven J., Terres J.M., Toth
T. (ur.). Italy, JRC Scientific and Technical Reports, 66 str.

Zupanc V., Nolz R., Cepuder P., Bračič-Železnik B., Pintar M. 2012. Determination of water balance components with high precision weighing lysimeter in Kleče. Acta Agriculturae Slovenica, 99, 2: 165 173. DOI: $10.2478 / \mathrm{v} 10014-012-0016-1$ 